\title{
HUKUK DEVIETI VE TERÖR
}

\author{
Prof. Dr. Fazıl Sağlam \\ Yıldız Teknik Üniversitesi \\ İktisadi ve İari Bilimler Fakültesi
}

\section{Özet}

Makalede Federal Almanya Anayasa Mahkemesinin son birkaç yıl içinde verdiği üç karar esas alınarak hukuk devleti içinde terörle mücadele konusunun ana çizgileri saptanmaya çalıșılmıștır. Sunulan örnekler her şeyden önce terörle mücadelenin basit ve yüzeysel yaklaşımlarla, çözülecek bir konu olmadığını göstermiştir. Bu anlamda terörün özgürlüğü genişleterek önleneceği görüşü de ciddi bir dayanaktan yoksundur. Terörün hukuk yoluyla önlenmesi, son derece karmaşık ve uzmanlık gerektiren bir süreçtir. Bu süreç, iyi yetişmiş hukukçuların diğer sosyal bilim dallarının nesnel verilerini hukuk çatısı içinde içselleștirmesiyle bașarıya ulașabilir. Bunun için de siyasal ve ideolojik baskı ve oyunlara karșı gerçekten bağımsız ve güvenceli bir yargı organının varlığı zorunludur. Siyasal ideoloji, kendisine kestirme yollar bulmak için hukuku geriye iterse, bir süre sonra kendi ideolojisini uygulayacağı güvenilir bir hukuk ortam da bulamaz. Her özgürlük, güvence altına alınan nesnel içeriğine uygun olarak kullanılmasını sağlayacak sınırlamaları göze almak durumundadır. Ancak böyle bir anlayış, o özgürlüğün anayasal ölçütler ve hukuk devleti ilkeleri içinde sınırlanması, uluslararası bir nitelik kazanan terörle de aynı çerçevede mücadele edilmesi yönündeki talebi inandırıcı kılabilir.

Anahtar Kelimeler: Hukuk devleti, terörle mücadele, yargı bağımsızlığı, güvenlik, temel haklar ve özgürlüklerin sınırlanması.

\section{The Rule of Law and Terrorism}

\section{Abstract}

The article aims to present a discussion of the key issues relating to the fight against terrorism under the rule of law, based on three recent judgments of the German Constitutional Court. These cases illustrate that the fight against terrorism requires much more than a shallow and simplistic approach. In this regard, the argument that terrorism could be stopped by expanding liberties clearly lacks any sound basis. Preventing terrorism by means of law is a quite complicated process and thus requires expertise. Such a process can only achieve success with the effort of legal experts who have developed an understanding of the objective data provided by the social sciences. It also requires a truly independent judiciary protected against ideological and political pressures and maneuvres. Indeed, if the dominant political ideology pushes the law back to find shortcuts for its desired political ends, then it destroys the reliable framework of law necessary to practice its own ideological agenda as well. The article concludes that each of the fundamental freedoms must tolerate restrictions which will serve to guarantee their enjoyment in accordance with their objective content. Only such an understanding of fundamental freedoms can authenticate the demand that the fight against the increasingly-global terrorism should be carried on under the rule of law.

Keywords: Rule of law, fight against terrorism, judicial independency, security, resticting fundamental rights and freedoms. 


\section{Hukuk Devleti ve Terör}

\section{Konu ve Sorunsalın Açıklanması}

Başlıkta "özgürlük ve terör" ikilemini kullanmayışım bilinçli bir seçimdir. Bu seçim, anayasal anlamda özgürlüğü soyut bir değer olarak değil, içeriği ve kapsamı nesnel olarak belirli ve o nedenle de daha sağlam bir güvenceye sahip alanlar olarak benimsememden kaynaklanıyor. Çünkü bir hak ve özgürlüğün anayasa tarafından güvenceye alınmış nesnel alanı, ancak yine anayasada yer alan belli neden, ölçüt ve kurallara göre daraltılabilir. Başka bir deyişle özgürlüğün anayasal sınırlaması da bu nesnel zeminin niteliğine uygun önlem ve araçlarla gerçekleştirilmek zorundadır. Bu anlamda anayasal hak ve özgürlük somut olarak kullanılmaya elverişli bir güvence sağlar. Anayasal özgürlük açısından önemli olan da budur. Somut bir içeriği olmayan soyut özgürlük anlayışı, sanat ve felsefe için düşünceyi besleyen bir önem ve değer taşısa da anayasanın amaçladığ 1 somut kullanıma elverişli bir güvence sağlayamaz.

Aynı nedenle eğer özgürlük ve terör bir ikilemse, bu ikilemin belirlenmesi, bir yandan terörü önleyecek ve diğer yandan özgürlüğü güvence altına alacak hukuksal çözümlerinin aranması da ancak özgürlük kavramının belli bir nesnel içeriğe sahip somut kullanıma elverişli anayasal bir güvence olarak anlaşılmasıyla mümkündür. Aksi takdirde savaş propagandasını, ırksal, ve dinsel nefret savunuculuğunu ve terör ve şiddetin savunulmasını da özgürlük kavramı içinde algılamak kuramsal olarak mümkün olur. Böyle bir yaklaşımdan, "Ku Klux Klan" özgürlüğü”ne, "Hitler"in yaptıklarını ya da soykırımı savunma özgürlüğüne, laik bir ülkede şeriatı uygulama, ya da kamusal alanda dinsel simgeleri kullanma özgürlüğüne geçmek, daha radikal bir anlatımla teröristten özgürlük ya da din savaşçısı üretmek artık bir an meselesidir.

Bunlar, sevgili Yavuz SABUNCU ile sohbetlerimizde üzerinde en çok durduğumuz sorunlardı. Yavuz, terörle mücadelede özgürlüğün anayasal alanlarının belli bir ölçüde daraltılmasının kaçınılmaz olduğunu çok iyi 
kavramakla birlikte, bunun otoriter eğilimlere yönelişin bir bahanesi olarak kullanılması olasılığına karşı da son derece duyarlı bir anlayışa sahipti. Demokrasinin korunması açısından bu ikilemin zorunlu kıldığ 1 hassas dengenin otorite lehine bozulma tehlikesi, Yavuz'un o kendine özgü, yer yer iğneleyici ve ironik uslubuyle sürekli olarak dile getirdiği bir sorundu. Yavuz aynı uslubu, özgürlüğü korumak için onun kullanımını sınırlayan kimi kuralları kaldırmaktan başka bir fikir üretemeyen, soyut özgürlük anlayışını savunayım derken özgürlügün somut kullanımını tehlikeye düşürdüklerinin farkında olmayan saf aydınlara karşı da kullanmaktan çekinmemiştir.

Bu nedenle Yavuz'un anısına çıkarılacak bir ARMAĞAN'da teröre karş1 alınacak önlemlerin hukuk devleti ilkeleriyla nasıl bağdaştırılması gerektiği konusunu işlemenin, onu anısına uygun düşeceğine inanıyorum. Özgürlüğü sınırlamadan terörü önlemenin bir yolu yoktur. Önemli olan bu sınırlamanın ölçüsünü doğru değerlendirmektir. Bunun için de yapılacak düzenlemelerle ilgili tartışmaların önyargısız ve sağduyulu olarak yürütülmesi gerekir.Yabancı hukuklarda sıkça rastladığımız bu tür tartışmalar için Türkiye'de sağlıklı bir ortam bulunduğunu söylemek güçse de, en azından bunun denenmesi gerekiyor. Yabancı hukuklarda böyle bir tartışma ortamını Türkiye için de verimli kılacak çeşitli örnekler var. Ama bizim burada işleyeceğimiz örnekler Almanya ile sınırlı olacak. Örnekler, Alman Anayasa Mahkemesi'nin son yıllarda verdiği kararlardan seçilmiştir. Bunlar daha da çoğaltılabilir. Bunlara belli yasa girişimleri üzerindeki tartışmalar ve uluslararası yaptırımların değişen nitelik ve özellikleri de eklenebilir. Ancak yazının çerçevesi tüm sorunların işlenmesine imkan vermiyor.

\section{11 Eylül Saldırısına Benzer Saldırılara Karşı Almanya'daki Yasal Düzenlemeler ve Bunlara Ílişkin Federal Anayasa Mahkemesi Kararları}

\section{A. Hava Araçlarının Saldırı Silahı Olarak Kullanılması ile İlgili Yasal Düzenleme ve Ílgili Federal Anayasa Mahkemesi Kararı}

\section{1) Yasal Durum}

Almanya'nın Frankfurt a/M kentinde 5 Ocak 2003 tarihinde bir spor uçağı silah tehdidiyle kaçırılmış, uçağı denetimi altına alan kişi, kendisine ABD ile bir telefon görüşmesi sağlanmadığı takdirde uçağı Avrupa Merkez Bankası üzerine düşüreceği tehdidinde bulunmuştur. Bunun üzerine uçakla ilgili ilk tedbirler alınmış ve tehdit altındaki yerlerin boşaltılması sağlanmıştır. Ancak 
yarım saat sonra uçağ kaçıran kişinin bir akıl hastası olduğu anlaşılmış, istediği telefon görüşmesi sağlandıktan sonra da bir direnç göstermeden teslim olmuştur.

Bu olaydan iki yıl kadar sonra Almanya'da hava trafiğinin güvencesiyle ilgili yasa köklü bir biçimde yenilenmiş ${ }^{1}$ ve yasanın 13., 14. ve 15. paragraflarında silahlı kuvvetlerin müdahalesine olanak tanıyan kurallara yer verilmiştir. Bunlardan anayasal sorunla doğrudan ilgili olan 14. paragraf aynen şöyledir:

"§ 14 (1) Silahlı kuvvetler, ăğr bir felaketin ortaya çıkmasını önlemek amacıyla hava sahasındaki uçuş araçlarını geri püskürtebilir, inişe zorlayayabilir, silah gücü kullanma tehdidinde bulunabilir veya uyart atışı yapabilir.

(2) Birden çok olası önlemler içinden tahminen bireylere ve kamuya en az zarar verecek olanın seçilmesi zorunludur. Alınan önlem, amacının gerektirdiği sürede ve genişlikte uygulanmalıdır. Önlemin yol açacağı zarar, hedeflenen başarlya göre göze çarpacak derecede bir ölçüsüzlük içinde olmamalıdır.

(3) Doğrudan doğruya silah gücünün kullanılmasina, ancak mevcut koşullara göre uçuş aracının insan yaşamına karşı kullanılacağının anlaşılması ve bunun o andaki tehlikenin önlenmesi için tek çare olarak kabul edilmesi halinde izin verilebilir.

(4) Üçüncü fikradaki önlemin alınmasına yönelik emir, ancak Federal Savunma Bakanı tarafindan, kendisine vekalet edilme durumu söz konusu olduğunda ise ancak Bakanlar Kurulu'nun onu temsile yetkili üyesi tarafindan verilebilir." 2

1 Gesetz zur Neuregelung von Luftsicherheitsaufgaben vom 11. Januar 2005 : BGBl I S. 78, metinde LuftSiG olarak kısaltılacak.

$2 \S 14-(1)$ Zur Verhinderung des Eintritts eines besonders schweren Unglücksfalles dürfen die Streitkräfte im Luftraum Luftfahrzeuge abdrängen, zur Landung zwingen, den Einsatz von Waffengewalt androhen oder Warnschüsse abgeben.

(2) Von mehreren möglichen Maßnahmen ist diejenige auszuwählen, die den Einzelnen und die Allgemeinheit voraussichtlich am wenigsten beeinträchtigt. Die Maßnahme darf nur so lange und so weit durchgeführt werden, wie ihr Zweck es erfordert. Sie darf nicht zu einem Nachteil führen, der zu dem erstrebten Erfolg erkennbar außer Verhältnis steht.

(3) Die unmittelbare Einwirkung mit Waffengewalt ist nur zulässig, wenn nach den Umständen davon auszugehen ist, dass das Luftfahrzeug gegen das Leben von Menschen eingesetzt werden soll, und sie das einzige Mittel zur Abwehr dieser gegenwärtigen Gefahr ist. 
Bu karallardaki anayasal sorun üçüncü fikrada kendini gösteriyor. Zira bu fikrada kaçırılan uçağı düşürme olanağı tanınmış. Bu da uçaktaki masum insanların yaşamına başka insanların yaşamını korumak amacıyla son vermenin anayasaya uygun olup olmadığı sorununu doğuruyor.

Nitekim bu sorun anayasa şikayeti yoluyla Federal Anayasa Mahkemesi önüne geldi. Davayı açanlar da şikayetlerini doğrudan doğruya Yasa'nın 14. paragrafının 3. fikrasına yönelttiler ve bu kuralın suçun faili olmayan, aksine suçun kurbanı durumundaki insanların kasten öldürmesine cevaz verdiğini ve bu nedenle insan onurunun dokunulmazlı̆ 1 (GG m. 1/1) ile yaşam hakkının (GG m.2/2) özüne dokunduğunu (GG m.19/2) ileri sürdüler. ${ }^{3}$

Aşağıda Federal Anayasa Mahkemesi kararı değerlendirilirken, yalnızca inceleme konusu ile doğrudan ilgili noktalar açıklanıp tartışlacak, anayasa şikayetinin koşulları ya da ilgili Yasa'nın Federal Konsey'in onayını gerektirip gerektirmediği gibi Türk Hukukunu doğrudan ilgilendirmeyen sorunlar üzerinde durulmayacaktır.

\section{2) Federal Anayasa Mahkemesi Kararı ${ }^{4}$}

\section{a) Davada Dinlenen Görüşler:}

Federal Anayasa Mahkemesi, kararını vermeden önce konuyla ilgili gördüklerinin düşüncelerini almış ve duruşmada da kendilerini dinlemiştir. Bunlardan Federal Meclis, ve Federal Hükümet ile Bavyera ve Hessen Eyaletleri temsilcilerince savunulan görüşler, daha çok Yasa ile ilgili yetki sorunlarının karşılıklı tartışılması biçimindedir. Federal Meclis ve Federal Hükümet Yasa'nın federal düzeyde düzenlenmesinin Anayasa'ya uygun olduğunu savunurken adı geçen iki eyalet, yetkinin aşıldığı görüşündedir. Almanya'nın federal yapısından kaynaklanan bu sorunlar konumuzu doğrudan ilgilendirmemektedir. Ancak bu bağlamda yukarda sayılanlardan hiçbirinin dava konusu kuralda bir temel hak ihlali görmediklerini belirtmek gerekir.

aa) Federal Meclis savunmasında amacın "daha yüksek bir ölü sayısının önlenmesi” $(48)^{5}$ olduğunu, yasama organının bu bağlamda hareketsiz kalma

(4) Die Maßnahme nach Absatz 3 kann nur der Bundesminister der Verteidigung oder im Vertretungsfall das zu seiner Vertretung berechtigte Mitglied der Bundesregierung anordnen. ...

3 “GG“ Alman Anayasası'nın kendi dilindeki kısaltılması olup metinde de bu anlamda kullanılacaktır.

4 BVerfG, 1 BvR 357/05 vom 15.2.2006, Absatz-Nr. (1 - 156), http://www.bverfg.de/ entscheidungen/rs20060215_1bvr035705.html 
ile yapilabileceklar arasında en uc noktada yer alan bir düzenleme yapma seçenekleri ile karşı karşıya kaldığını, geleneksel ceza hukuku kavramlarıyla açıklanamıyan koşullar nedeniyle uçağı düşürme sorumluluğu yüklenmiş kişilerin bu eylemlerini meşru kılmak gerektiğini, bunun için daha büyük bir hukuksuzluğu önlemek amacıyla hukuksuz bir davranışı hukuka uygun hale getirme sonucunu doğuran bir düzenleme yapma zorunda kalındığını (50), bu düzenlemede uçağı düşürme koşullarının son derece dar tutulmasına özen gösterildiğini (49) belirtmektedir.

Davada Meclis'teki muhalif grubun (Yeşiller) görüşünün de alınması çoğulcu bir demokrasi için güzel bir örnektir. Yeşillerin açıklamasında dava konusu kurala Anayasa'ya uygun bir anlam verme çabası göze çarpmaktadır. Dava konusu kurala, uçakta kaçırma olayı ile ilgisiz kimselerin bulunması halinde uçağın düşürülemiyeceği düşüncesiyle destek verdiklerini belirten Yeşiller, anılan kuralın bir insan yaşamının başka bir insan yaşamına karşı gerek nicel ve gerekse nitel yönden yürütülecek bir değer tartısına cevaz vermediğini, aksi takdirde kuralın Anayasa'ya aykırı olacağını savunmuşlardır. (51, 52). Ancak bu yorum, kuralın açıklığı karşısında pek de inandırıc1 gözükmemektedir. Nitekim aşağıdaki açıklamalarda da görüleceği üzere Federal Anayasa Mahkemesi bu yoruma itibar etmemiş̧ir (81).

bb) Federal Hükümet'in savunması da Federal Meclis'inkine paralel niteliktedir. Ancak Federal Hükümet'in savunmasında yer alan bir bölüm, önemli bir Batı ülkesi yönetiminin terör kurbanlarına bakış açısını gösteren kaygı verici bir özellik taşımaktadır:

"Hava trafiğinin günümüzde karşı karşıya bulunduğu tehdit karşısında, yolcuların uçağa binmekle kendilerini bir tehlikeye soktuklarının bilincinde olmaları gerekir. ... Kullanılan silahın ayrlmaz bir parçası durumundaki bu kişilerin kurtarlması zaten mümkün değildir."(56) ... "Onlar iradeleri dışında da olsa bir silahın parçası konumundadır." (57)

Adeta bir robottan çıkmış izlenimini uyandıran bu cümleleri Federal Anayasa Mahkemesi'nin nasıl değerlendirdiği konusuna birazdan döneceğiz. Ancak bu bağlamda şunu söylemeden geçemiyoruz: Anayasası "İnsan onuruna dokunulamaz" cümlesiyle başlayan bir ülkenin hükümeti, yaşamlarını korumakla yükümlü olduğu insanların, -başkalarının yaşamını

5 Kararlarla ilgili olarak parantez içinde verdiğimiz rakamlar karar metnindeki kenar numaralarını ifade etmektedir. 
korumak amaciyla da olsa- hukuk yoluyla öldürülmesini, üstelik sorumluluğu onlara yıkmaya çalışarak açıklayacaksa, Anayasasındaki o kuralın hiçbir önemi kalmamış demektir.

cc) Buna karş1l1k "Silahlı Kuvvetler Federal Birliği”"nce ${ }^{6}$ verilen görüşün bir bölümü hukuk devleti ilkesiyle ilgilidir. $\mathrm{Bu}$ görüşte dava konusu düzenlemenin belirlilik ilkesine aykırı olduğu, yaşamın yaşama karşısı tartılmasını öngören bu kuralda böyle bir tartı için yeterli belirginlikte ölçütlere yer verilmediği, bu eksikliğin harekete zorlanan askerlerin itaat yükümlülüğü ile kendisi tarafından alınacak olan kişisel vicdani karar arasında ağır bir çatışmaya yol açacağı belirtilmektedir. Ayrıca askerleri cezai ya da hukuki sorumluluktan kurtaracak güvenilir bir düzenlemenin de bulunmadığı ifade edilmektedir. (67)

dd) "Pilotlar Birliği"7 ve "Bağımsız Uçuş Refakatçileri Örgütü"nce ${ }^{8}$ verilen görüşlerde de mesleklerinin gereklerine uygun uyarılar yer almaktadır. Örneğin Pilotlar Birliği'nin görüşünde, düzenlemenin elverişlilik ve gereklilik ilkeleri yönünden sakıncalı olduğu, 14. paragraf uyarınca verilecek karardan önce silahlı tehdit altındaki uçuş aracı ile ilgili olarak 15/1. paragrafa ${ }^{9}$ göre yapılması zorunlu olan incelemede kazanılacak bilgilerin en ideal hava koşullarında bile kesinlikten yoksun olacağı, uçak kaçıran kişinin olası motivasyonu ile kaçırma amacının son ana kadar spekülatif olmaktan öteye geçemeyeceği, güvenilir sonuç getirecek bir kararın zaman sıkışıklığı nedeniyle genellikle gecikme ile sonuçlanacağ peşinen ölçüsüz bir reaksiyonun göze alınmasıyla işletilebileceği belirtilmektedir (68).

Bağımsız Uçuş Refakatçileri Örgütü’nün görüşünde ise uçaktaki koşulların yerden yanlış değerlendirilme tehlikesine dikkati çekilmekte ve bu bağlamda 14/3. paragraf koşullarının bulunup bulunmadığını yerden değerlendirmenin fiilen mümkün olmadığı, Savunma Bakanlığı'nın karar vermek üzere gereksinim duyacağ tehlike bölgesinden alamayacağı, edineceği bilgilerin zorunlu olarak teröristlerin tehdit ve baskısı altındaki pilot ya da kabin personelinden dolaylı olarak geleceği, ayrıca bunlardan bağımsız olarak uçaktaki durumun saniye

6 "Der Deutsche BundeswehrVerband"

7 "Die Vereinigung Cockpit"

8 "Die Unabhängige Flugbegleiter Organisation UFO"

9 Bu fikranın ilk cümlesi şöyledir: "§ 14 fikra 1 ve 2 uyarınca alınacak önlemler, ancak gerekli inceleme ve kontroller yapıldıktan sonra ve uyarı ve yol değiştirme yönündeki denemelerin başarısız kalması üzerine alınabilir." 
hızıyla değişebileceği ve bu bilginin iletişim yollarının uzunluğu nedeniyle yeteri hızla aktarılamıyacağı belirtilmektedir (70).

Bütün bu görüşleri özetlememin nedeni, konunun boyutlarının genişliği hakkında bir fikir vermektir. Ne yazık ki Türk Anayasa Mahkemesi, soyut ve somut norm denetimi ile sinırlı kaldığ 1 için bu tür bir değerlendirme zenginliğinden yoksundur. Ancak kendi gereksinim duyduğu istisnai durumlarda benzer bilgilere ulaşmak üzere belirleyeceği kişileri dinleme yoluna gitmektedir. Kuşkusuz anayasa şikayeti yolunun benimsenmesi halinde bu gereksinim, somut olayın (ya da bu davada olduğu gibi kuralın somut ve doğrudan etkisini hisseden birey ve bireylerin) dürtüsüyle daha da genişleyecektir.

\section{b) Kararın Gerekçesi:}

Federal Anayasa Mahkemesi tüm görüşleri dinledikten sonra başvuruyu haklı bulmuş ve 14/3. paragrafın gerek biçim ve gerekse maddi yönden iptaline karar vermiştir. Biçim yönüyle iptal daha önce de belirttiğimiz gibi fereral ve federe organlar arasındaki yetki paylaşımı ve buna ilişkin kurallardan kaynaklanan bir sonuçtur. $\mathrm{Bu}$ nedenle burada yalnızca bizi doğrudan ilgilendiren maddi yönden iptal gerekçeleri üzerinde durulacaktır. Bunlar,

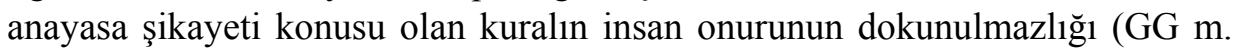
1/1) ile yaşam hakkına (GG m. 2/2) aykırılığını açıklayan gerekçelerdir.

Ancak hemen belirtelim ki Federal Anayasa Mahkemesi kararında bu iki hak alanı birbirinden bağımsız ve kopuk alanlar olarak ele alınmamış, insan onuruna dokunulmazlık kuralının yaşam hakkının sınırlanmasında gözönünde tutulması gereken en temel değer olduğu belirtilerek bu iki hak alanı arasındaki ayrılmaz nitelikte bir bağlantı kurulmuştur. Bu yaklaşım doğaldır. Çünkü Federal Anayasa Mahkemesi'ne göre, “İnsan yaşamı insan onurunun canlı temelidir" ve bu birlik en yüksek anayasal değer ve anayasayı taşıyan temel ilkedir. ${ }^{10}$ (119). Bu nedenle gerekçede önce insan onuruna dokunulmazlık kuralı Mahkeme'nin diğer kararlarından yapılan alıntılarla aydınlatılmakta (aa), daha sonra her iki hak alanının anılan bağlantısı içinde, şikayet konusu kuralın yaşam hakkına aykırılığı bütün boyutlarıyla işlenmektedir (bb). Son bir bölümde ise uçak düşürmenin hangi durumlarda insan onuru ve yaşam hakkının bir ihlali sayılmayacağı konusu üzerinde durulmaktadır (cc). Aşağıda da aynı sira izlenecektir.

10 "Das menschliche Leben ist die vitale Basis der Menschenwürde als tragendem Konstitutionsprinzip und oberstem Verfassungswert" (BVerfGE 39, $1<42>$; 72, 105 $<115>$; $109,279<311>$ ) 


\section{aa) İnsan Onuruna Dokunulmazlık Kuralı}

Kararda bu açıdan yapılan açıklamalar şöyle özetlenebilir: "Yaşam hakkı ve insan onuru arasındaki ilişki, bir yandan devletin, insan onurunu ihlal edecek nitelikte önlemlerle yaşam hakkına müdahale etmesini yasaklamakta, öte yandan devlete her insanın yaşamını üçüncü kişilerin saldırısına karşı da koruma yükümlülüğ̈̈ getirmektedir ${ }^{11}$. Bu yükümlülük herşeyden önce insanın devlet tarafından yalın bir nesne durumuna düşürülmesini yasaklamaktadır (121 ve orda anılan kararlar). Buna göre kamu gücü, insanın salt insan olmas1 nedeniyle sahip olduğu kişiliğe ve ona bağlı değere riayet etmek ve böylece insanın hak sahibi bir süje olma niteliğini kuşkuya düşürecek her herhangi bir davranıştan kaçınmak zorundadır. Ne zaman böyle bir davranışın söz konusu olacağı ise, bireysel olayda uyuşmazlığın özgül (spesifik) durumuna göre somutlaştırılmalıdır. (121 ve orada anılan kararlar).

\section{bb) Yaşam Hakkı:}

Uçak düşürme koşullarının oluşmasıyla yolcular ve personel, kendileri açısından çıkışı olmayan bir konuma girerler. Artık onların yaşam koşullarını başkalarına bağlı olmaksızın kendi seçimleriyle belirlemeleri söz konusu değildir (123). Bu durumda onlar yalnızca terör fail ya da faillerinin bir nesnesi olmakla kalmayıp, şikayet konusu kuralı uygulama kararı alan devlet tarafindan da başkalarını kurtarma operasyonunun yalın bir nesnesi durumuna düşürülmüş olurlar. (124). Böyle bir duruma "korumasız ve çaresiz olarak" terkedilmiş olmak, muhatapların onur sahibi ve devredilmez hakların süjesi olma niteliğinin hiçe sayılması demektir. Başkalarının kurtuluşu aracı olarak öldürülmeleri, onları nesneleştirir ve aynı zamanda hak sahibi olmaktan çıkarır. Devletin bu şekilde tek yanlı olarak onların yaşamları üzerinde tasarrufta bulunması, kendileri yardıma muhtaç olay kurbanlarının salt insan olmaları nedeniyle sahip oldukları değerin yok edilmesi anlamına gelir (124).

11 Ibler, devletin koruma yükümlülüğü öğretisini geliştirmekle, Mahkeme’nin yaşam hakkının koruma alanını da genişlettiğini belirtmektedir, bkz. Martin Ibler, "Grundrechtliche Freiheit im Zeitalter des Terorismus - aus deutscher Perspektive" : Deutsch - Türkisches Forum für Staatsrechtslehre IV Berlin 2006 Toplantısına sunulan bildiri metni:, s. 16; Alman hukuku bakımından temel hak ve özgürlükler ilke olarak olumsuz statu hakları niteliği taşıdığından, Mahkeme'nin koruma yükümlülüğü yönündeki öğretisi, bu niteliği aşan bir koruma alanı sağlamaktadır. Türk Anayasa Hukuku bakımından devletin bu yükümlülüğü, genel olarak Anayasa'nın 5. maddesinde pozitif bir temele sahip kılınmıştır. 
Kararda bu açıklamalara ek olarak uçuş aracının darlı̆̆ı, uçuş ve kaçırma koşullarındaki değişkenlik, yer ile iletişimin içinde bulunduğu yetersizlikler, zaman sıkışıklı̆g 1 gibi 14/3. paragraf uyarınca verilecek düşürme kararının zorlukları üzerinde durulmakta, emrin erken ya da geç verilmesinin yol açacağ 1 ölçüsüzlük ve yanlışlıklara işaret edilerek, bu koşullar altında yetkili makamca verilecek kararın genelde güvenilir bilgilerden çok, kuşkuya dayanmak zorunda kalacağı sonucuna varılmaktadır. (125-129). Bu açıklamalarda gerek "Pilotlar Birliği”nin ve gerekse "Bağımsız Uçuş Refakatçileri Örgütü”"nün görüşlerinin etkili olduğu görülmektedir.

Kararda dikkati çeken bir başka nokta, düşürülecek uçaktaki yolcu ya da personelin her an potansiyel tehlike içinde olduğunun bilincinde olması ve bunu göze alarak uçağa binmesi, böyle bir durumda ölümün zaten önlenemez olması ya da uçağın başkalarının ölümüne yol açacak bir silah gibi kullanılması halinde yolcuların da bu silahın bir parçası haline gelmesi gibi savunmalara Federal Anayasa Mahkemesi'nin hiç itibar etmemiş olmasıdır. Hatırlanacağı üzere bunlar, hükümetin savunmasında yer alan düşüncelerdir. Mahkeme kararında, düşürülme olasılığı göze alınarak uçağa binildiği iddiası, "realist bir temelden yoksun yaşamın doğal akışına yabancı bir varsayım" (131) olarak değerlendirilmektedir, Ölümün kaçınılmazlığı argümanı ise şu açıklamalarla çürütülmektedir: İnsan yaşamı ve insan onuru, bireyin fizik varlığının süresine bakılmaksızın aynı anayasal korumadan yararlanır. Bunu yadsıyan ya da sorgulayan herkes, kaçırılan uçakta seçeneksiz bir çaresizlik içinde bulunan terör kurbanlarını, insan onurunun asıl sayg1 gerektirdiği bir konumda saygıdan yoksun bırakmış olur (132). Uçaktaki terör kurbanlarının silaha dönüştürülmüş uçağın bir parçası oldukları iddiası ise özetle şöyle karşılanıyor: $\mathrm{Bu}$ görüş neredeyse gizlemeye gerek duymaksızın şunu dile getiriyor: Böyle bir olayın kurbanı artık insan olarak değil, bir nesnenin parçası olarak görülmeli ve nesneleştirilmelidir. Böyle bir anlayışı, Anayasa'nın, insanı kendi kaderini özgürce belirleyen bir mahluk olarak değerlendiren ve bu nedenle de onun, devlet davranışının yalın nesnesi durumuna düşürülemeyeceğini öngören insan portresiyle bağdaştırmak olanaksızdır (134).

Mahkeme, uçağın yolcu ve personeli ile birlikte düşürülmesinin daha yüksek sayıdaki insanların yaşamını koruma yükümlülüğünün bir gereği olduğu iddiasını da geçerli görmemiştir. Mahkeme bu konuda özetle şunları söylemektedir: Şikayet konusu kural, bir terörist saldırının uçaktaki kurbanlarının da devletten kendi yaşamlarını koruma konusunda bir talep haklarının bulunduğunu görmezden gelmektedir. Onların bu korumadan yoksun bırakılmaları bir yana, çaresiz durumdaki bu insanların yaşamı devlet tarafindan doğrudan ihlal edilmektedir. Böylece 14. maddenin 3. fikrası uyarınca yapılacak her müdahale, bu insanların hak süjesi niteliğini insan onuruyla 
bağdaşmıyacak bir biçimde çiğnemektedir. Bu fiille başka insanların haklarının korunacak olması, bu gerçeği değiştiremez (139).

\section{cc) Düzenlemenin Geçerli Olacağı Alan:}

Yukarda özetlediğimiz gerekçelerden sonra hangi durumda şikayet konusu düzenlemenin geçerli olacağı, ana hatlarıyla belirginlik kazanmıştır. Ancak Mahkeme 14/3. paragrafi biçim yönünden de iptal etmesine rağmen bu konuya önemli bir bölüm ayırmıştır. Bu yöndeki açıklamaların iptal kararından sonra yasa koyucu tarafindan yapılacak yeni bir düzenlemeye yol gösterici bir işlevi olacağ1 düşünülebilir. Ayrıca bu açıklamalar, konumuzun aydınlatılmasında da dolaylı olarak yararlı olabilir. Mahkemeye göre, 14/3. paragrafin insan onurunun dokunulmazlığı ve yaşam hakk1 ile bağdaşabilmesi, ancak anılan kuralda öngörülen silahlı müdahalenin, insansız bir uçağa yöneltilmesi ya da uçakta sadece onu bir suç silahı olarak yerdeki insanların yaşamlarını yok etmek üzere kullanacak kimselerin bulunması halinde mümkün olabilir. Buna göre bir uçağı başkalarını öldürecek bir silah olarak kullanmak isteyenlere karşı devletin insan yaşamını koruma yükümlülüğünü yerine getirmesi, suç girişiminde bulunanları nesne durumuna düşürmez (141). Buna bağlı belirsizlikler de suç failinin sorumluluk alanı içinde kalır. (142, 143). Ancak Mahkeme bu tespitlerle yetinmemiş, şikayet konusu kuralın sadece suç failleri ile sınırlı olarak uygulanmasının ölçülülük ilkesine uygun olup olmadığını da ayrıca denetlemiştir. Mahkeme'ye göre bu koşullarda uçak düşürmenin amaca ulaşma bakımından elverişsiz bir önlem olduğu söylenemez. Önlem gereklidir, çünkü aynı derecede etkili olup da suç failinin yaşamını ihlal etmeyecek ya da daha az ihlal edecek bir başka önlemin tespiti mümkün görülmemiştir. Nihayet söz konusu önlem dar anlamda da ölçülülük ilkesine uygundur. Çünkü uçak düşürme kararının koşullarının gerçekte var olması halinde, bu karara bağlı temel hak ihlali ağır da olsa korunacak hukuksal değerlerin ağırlığı karşısında ölçülü ve ilgilisinin göze alması gereken bir önlemdir $(144-155)^{12}$.

\section{c) Kararın Değerlendirilmesi}

Federal Anayasa Mahkemesi'nin yukarda incelenen kararıyla ilgili kısmi değerlendirmeler satır aralarında yapılmıştır. Genel bir değerlendirme yapmak gerekirse, Mahkeme'nin insan onuru ve yaşam hakkını büyük bir titizlikle koruduğu söylenebilir. Ancak yasama organının işaret ettiği (hareketsiz kalma ile yapılabileceklar arasında en uc noktada yer alan bir düzenleme yapma)

12 Karş. Ibler, agm, s. 18 
ikilemi hatırlanacak olursa, Mahkeme kararının ilke olarak "hareketsiz kalma" seçeneği ile sonuçlandığını söylemek mümkündür. Başka bir deyişle Mahkeme'nin verdiği karar, terör tehdidi altındaki insanların (uçaktakilerin ya da yerdekilerin) yaşamları için bir çözüm getirememiştir. Esasen bu konularda çözüm üretmek Mahkeme'nin görevi olmayıp, yasa koyucunun ve yürütme organının görevidir. Bu tespit bir eleştiri olmayıp, varılan noktanın bir ifadesidir. Mahkeme bunun farkında olduğu içindir ki verdiği iptal kararına rağmen kuralın geçerli olabileceği durumları uzun uzadıya açıklama ihtiyacını hissetmiştir. İçinde sadece suç faillerinin yer aldığı uçaklar bakımından sınırlı bir çözüme işaret eden bu açıklamaların bir özeti yukarda verilmiştir. Ancak belirtmek gerekir ki bunlar, 11 Eylül Olayı'ndan sonra yeni bir nitelik kazandığ 1 anlaşılan uluslararası boyutta bir terör olgusunu tam karşılamaktan uzaktır. Ne var ki bunun alternatifi de, insan onuru ile belirlenmiş bir yaşam hakkının gerektirdiği koruma ve güvenceden kimilerinin yoksun bırakılmasıdır. $\mathrm{Bu}$ da tercih edilecek bir seçenek değildir. İçinde bulunduğumuz aşama, hukuksal düzeyde adeta bir çeşit kaderciliği çağrıştıran ama bir biçimde aşılması gereken bir çözümsüzlük yumağı olarak karşımıza çıkmaktadır.

Ancak kararda yer alıp ta bizim değinmediğimiz bir konu, bu bağlamda sınırlı da olsa bir önem kazanmaktadır. Değerlendirmeyi bununla tamamlamak yerinde olur.

Kararda "Berlin Anayasa Şerhi"ne (Berliner Kommentar) gönderme yapılarak burada yer alan bir görüş tartışılmaktadır. Bu görüşe göre, devlet bütünlüğ̈̈nün onu çökertmeyi ve tahrip etmeyi amaçlayan saldırılardan korunması, ancak bireyin kendini feda etmesiyle mümkün olacaksa, bireyin bu yönde bir yükümlülüğünün bulunduğunu kabul etmek gerekir ${ }^{13}$. Mahkeme şikayet konusu kural açısından bu görüşü yerinde bulmamıştır. Mahkeme bu konuda Hava Güvenlik Yasası'nın (LuftSiG) 14/3. paragrafının uygulama alanında devletin bütünlüğünü, hukuk ve özgürlük düzenini ortadan kaldırmaya yönelik saldırılara karşı savunma olgusunun yer almadığını belirtmekle yetinmiş ve anılan nitelikte bir dayanışma yükümlülügünün olağanüstü yönetim usullerinin sağladığ 1 koruma mekanizmaları dişında hangi koşullarda söz konusu olabileceğinin incelenmesine bilinçli olarak girmemiştir (135). Mahkeme'ye göre Hava Güvenlik Yasası'nın (LuftSiG) 13 - 15. paragrafları, Anayasa'nın 35. maddesinin ikinci fikrasının ikinci cümlesinde yer alan "çok ağır bir felaket" kavramı ile sıkı bağlantı içinde düzenlemelerdir. Bu açıdan bakıldığında siyasal motifli de olsa bu tür bir felaketin varlığı için aranacak

13 Enders, in: Berliner Kommentar zum Grundgesetz, Bd. 1, Art. 1 Rn. 93 (Stand: Juli 2005). 
koşullar arasında devleti ortadan kaldırmaya yönelik olma gibi olgular yer alamayacaktır. Bu nedenle 14/3. paragrafin uygulanması bakımından yukarda açıklanan anlamda bir dayanışma yükümlülüğünden söz etmek mümkün değildir (136).

Dikkat edilirse, burada belirleyici olan Alman Anayasası'nın eyaletlere yardım koşullarını düzenleyen 35/2. maddesindeki "çok ağır felaket" kavramıdır. Mahkeme'nin buna dayalı gerekçesinin karşıt kavramının bir açık kapı bıraktığını düşünmek mümkün gözükmektedir. Bunun üniter bir yapıda ne ifade edeceği, hukuk devleti ilkeleriyle bağdaşır nitelikte bir çözüme dayanak olup olamıyacağı ayrı bir tartışma konusudur.

\section{d) Türk Anayasa Mahkemesi'nin Yaşam Hakkı İle İlgili Kararı}

Değerlendirmemizi Türk Anayasa Mahkemesi’nin farklı bir boyutta da olsa, yaşam hakkını doğrudan ilgilendiren ilginç bir kararı ile tamamlamak anlamlı olabilir.

Anayasa Mahkemesi'nin 1999 yılında verdiği bu karar Terörle Mücadele Kanunu'nun Ek 2. maddesi ile ilgilidir. Bu maddeye göre, terör örgütlerine karşı yapılacak operasyonlarda, kolluk kuvveti görevlilerinin silah kullanmaları, teslim ol emrine itaat edilmeyerek silah kullanmaya teşebbüs edilmesi koşuluna bağlanmıştır. Bu koşulun gerçekleşmesi durumunda görevliler failleri etkisiz kılmak amacıyla, doğruca ve duraksamadan, hedefe karşı ateşli silah kullanabileceklerdir. Anayasa Mahkemesi'nin bu düzenlemeye yönelik iptal gerekçesi şöyledir:

(Anayasa'nın 17. maddesi ile) "güvence altına alınan yaşama hakkinı korumak için devlet her türlü önlemi almak yükümlülüğ̈̈ndedir. Yasa ile ancak zorunlu durumlarda silah kullanma yetkisi verilebilir. Silah kullanmaya yetki verilebilmesi için son fikrada sayılan durumlarda yetkililerin silah kullanma dışında başka olanaklarının bulunmaması gerekir.

Kuralda faillerin sadece "silah" kullanmaya teşebbüslerinden söz edilirken kolluk kuvveti görevlilerinin hedefe karşı "ateşli silah" kullanmalarından söz edilmiş; böylece faillerin kullanmaya teşebbüs ettikleri silahın ateşli silah olup olmadığına bakalmaksızın ve başka türlü etkisiz hale getirilmeleri olanağı gözetilmeksizin küçük bir müdahale ile önlenebilecek olaylarda dahi görevlilere ateşli silahlar kullanma yetkisi verilmiştir.

Buna göre, dava konusu kuraldaki teslim ol emrine uyulmamast ve silâh kullanmaya teşebbüs edilmesi, görevlilerin her zaman doğruca ve duraksamadan hedefe karşı ateşli silâh kullanmalarını zorunlu kılacak nitelikte bir durum değildir. Kimi olaylarda faillerin, can güvenliğini daha az tehlikeye 
sokan yöntemlerle de etkisiz hale getirilmeleri olanakl olabilir. Olaylarin özelliğine göre, bu yöntemlere başvurulmaksızın doğruca ve duraksamadan hedefe karşı "ateşli silâh" kullanılması yaşama hakkının zedelenmesi sonucunu doğurur. Bu nedenle kural, Anayasa'nın 17. maddesine aykırıdır. İtali gerekir." 14

Anayasa Mahkemesi'nin bu gerekçesi, aynı zamanda ölçülülük ilkesinin alt ilkesi olan "zorunluluk" ilkesinin de tipik bir uygulaması olarak değerlendirilmelidir. Ayrıca bu karar, yaşam hakkının korunması bakımından Federal Anayasa Mahkemesi'nin yukarda incelenen kararındaki gerekçelere paralel bir nitelik göstermektedir.

\section{B. "Eleyici Takip" (Rasterfahndung) ile Illgili Anayasa Mahkemesi Kararı}

\section{1) Olay}

"Rasterfahndung”, Türkçe'de „eleyici takip“ olarak çevrilebilecek bir arama yöntemidir. Bu yöntem, 2006 yılında ilginç bir Anayasa Mahkemesi kararına konu oldu. Bu yöntemle ilgili düzenleme, Kuzey Ren-Westfalya Polis Yasası'nın 31. paragrafında yer alıyor. Bu kural, çeşitli kurumlardaki (konut bildirim büroları, yabancılar bürosu, üniversite ve yüksek okullar gibi) kişisel bilgilerin belli bir merkezde toplanmasına yargıç kararı ile imkan tanıyor ve bunun koşullarını düzenliyor. Kuralda yer alan en önemli koşul, "eleyici takip" önleminin, eyaletlerin ya da federal devletin varllğına ya da güvenliğine veya bir kişinin vücuduna, yaşamına veya özgürlüğüne yönelik halihazır bir tehlikenin önlenmesi için gerekli olmasıdır. Böylece elde edilen bilgiler, belli ölçütlere göre bilgisayarda otomatik olarak elenip, sonunda terör örgütleri tarafindan ileride planlanacak terörist girişimlerde kullanılmak üzere „uykuda“ bekletildiği düşünülen potansiyel teröristlere ulaşma amaçlanıyor. Tabii burada da 11 Eylül Saldırıları belirleyici olmuş ve „uykuda bekletilen terörist“ arayışı da islami unsurlar üzerinde yoğunlaşmış. Bu kural, belirlenen özelliklere göre gerekli elemeleri zincirleme olarak gerçekleştirmek üzere 11.000 kişiye ait kişisel bilgiler esas alınarak uygulanmış. Konunun Anayasa Mahkemesi önüne gelmesi de ilginç. Bu uygulamanın gizli yapıldığını belirtmeye gerek yok. Ancak yasa, amaca uygun bilgiler elde edildikten sonra, elenmiş tüm bilgilerin silinmesini ve elemenin tamamlanmasından sonra, hakkında yeni önlemler uygulanacak kişilere, sonraki veri kullanım amacını tehlikeye düşürmemek kaydıyla durumun bildirilmesini öngörüyor (20). İşte böyle bir bildirimi alan 
Fas'lı bir öğrenci “eleyici takip" iznini veren Mahkeme kararının Yasa'ya ve Anayasa'ya aykırı olduğunu ileri sürerek önce gerekli kanun yollarına başvurmuş, bunların reddi üzerine de sorunu Anayasa Mahkemesi önüne getirmiş.

\section{2) Federal Anayasa Mahkemesi Kararı}

Federal Anayasa Mahkemesi'nin bu kararın $1^{15}$, ayrıntılarına girmek-sizin ilkesel düzeyde ele alacağız. Burada anayasal sorun, "eleyici takip" yönteminin kişinin kendisi hakkındaki bilgi ve verilerin kullanılmasını belirleme hakkını ihlal edip etmediği sorusunda düğ̈̈mlenmektedir. Federal Anayasa Mahkemesi, Alman Anayasası'nda açıkça yer almayan bu hakkı, daha önceki kararlarında insan onuruna dokunulmazlık kuralı (GG m. 1/1) ile kişiliği serbestçe geliştirme hakkı (GG m. 2/1) arasındaki ilişki ve bağlantıdan çıkarmıştır (69 ve orada gönderme yapılan kaynaklar). Mahkeme, alınan önlemin ilgili temel hakka bir müdahale teşkil ettiğini belirlemekle birlikte, bunun ölçülü olup olmadığını iki yönlü bir incelemeden geçirmiş, yasal müdahale yetkisi veren düzenlemeyi ölçülü bulurken, önlemin uygulanmasına ilişkin mahkeme kararını ölçülülük ilkesine aykırı bulmuştur ${ }^{16}$.

Federal Anayasa Mahkemesi bu ayırımı yaparken, kendisiyle diğer mahkemeler arasındaki yetki alanı konusunda geliştirdiği sürekli içtihata gönderme yaparak yasaların yorumlanması ve somut olaya uygulanmasının uzman mahkemelerin ${ }^{17}$ yetki alanı içinde kaldığını, ancak uzman mahkemelerin temel hak ve özgürlüklere dokunan bir karar verirken, bu hakların değer belirleyici güç ve etkisini uygulama aşamasında da yoruma yön verici nitelikte gözönünde tutmaları gerektiğini, bu nedenle ilgili kuralın alanını genişletici bir biçimde yorumlamak suretiyle ona, ilgili temel hakkın ihlaline yol açacak bir anlam ve içerik kazandıramıyacaklarını, çünkü yasa koyucunun dahi bu

15 BVerfG, 1 BvR 518/02 vom 4.4.2006, Absatz-Nr. (1 - 184), http://www.bverfg.de/entscheidungen/rs20060404_1bvr051802.html

16 Karş. Ibler, agm, s. 21.

$17 \mathrm{Bu}$ terim, anayasa yargısını diğer yargı yerlerinden ayırmak üzere Alman Anayasa Mahkemesi'nce kullanılan bir terimdir. Terim Alman öğretisinde de benimsenmiş ve yerleşmiştir. Sade yasaların somut olaya uygulanması konusundaki değerlendirmenin, bu konuda yetkili ve görevli kılınan mahkemelere ait olduğu, Anayasa yargısının yalnızca anayasanın üstünlüğünü koruma amacıyla sınırlı ve yardımcı (subsider) olarak devreye gireceği görüşünü esas alan bu terim, ideali daha iyi yansıtması bakımından tarafımızdan da tercih edilmiştir. Tabii bu terim, gerçeği ve ideali sade yasalar yönünden yansıtan bir terimdir. Anayasa yönünden uzman mahkemenin Anayasa Mahkemesi olduğu kuşkusuzdur. 
anlamda bir yasa koyma yetkisi bulunmadığını belirtmektedir (155 ve orada anılan kararlar).

Mahkeme bu ilkeleri somut olaya uygularken, yasada yer alan "halihazır tehlike" koşulunun mahkeme kararında "tehlike olasılı̆̆ı"na indirgendiği, böylece somut tehlike koşulundan Anayasa'nın cevaz vermediği biçimde vazgeçilmiş olduğu, böyle bir yorumun ise "eleyici takip"in yasada somutlaşmış bulunan anayasal koşullarıyla bağdaşmadığı sonucuna ulaşmaktadır (156-162).

\section{3) Kararın Değerlendirilmesi}

a) Kararda yasa ve uygulama düzeyinde yapılan ikili ayırım, anayasa şikayeti kurumunun yerine getirdiği önemli bir işlevi somutlaştırması bakımından önem taşıyor. Böyle bir çözüme hukukumuzda ulaşmak mümkün değildir. Çünkü Anayasa Mahkememiz, yalnızca norm denetimi yapmakta, normun uygulanışındaki temel hak ihlallerini inceleyememektedir. Anayasa şikayetine yer vermeyen bir yargı denetimin eksikliği bu örnekte çok açık bir biçimde görülmektedir.

b) Kararda yer alan bir karşı oy yazısından kısaca söz etmek, gerek karar sürecinde neyin tartışıldığını görmek ve gerekse inceleme konumuzun ana sorunlarına işaret etmek bakımından yararlı olabilir. HAAS'ın karşı oy yazısında özgürlüğün devletçe sağlanmış bir güvenliğe gereksinim duyduğu, böyle bir güvenlik olmadan özgürlüğün yaşamla doldurulamıyacağı, özgürlüğün ancak böyle bir temel üzerinde gelişebileceği, bu nedenle de özgürlük ve güvenlik arasında ayrılmaz nitelikte bir anlam ve nesne bağlantısı bulunduğu, kişinin, yaşamına ve sağlığına başkalarınca yapılacak saldırıların korkusundan uzak kalması ve böylece özgürlüğün güçlendirilmesi için, önemsiz müdahalelerin göze alınması gerektiği vurgulanmaktadır (174). Bu düşünsel temelden hareket eden HAAS, "eleyici takip"te kullanılan bilgilerin, daha önce özellikle kamu makamlarına ilgilisi tarafından açıklanmış ve hafızaya alınmış bilgilerle sınırlı kaldığını, bu durumun müdahalenin önem ve yoğunluğunu azalttığını, cinsiyet, konut, ana-baba ve öğrenim dalı gibi bilgilerin zaten gizli olmadığını (170), aynı şeyin dini bilgiler açısından da geçerli olacağını, çoğunluk görüşünün aksine bu bilgiye göre yapılacak elemenin kişileri damgalayıcı etkisinden söz edilemiyeceğini, çünkü aşırı (fundamentalist) dincilerin aranmasında dine mensubiyetin zorunlu bir hareket noktası olduğunu (171), “eleyici takip" yönteminin telekominikasyonun izlenmesi ile karıştırılmaması gerektiğini, çünkü eleyici takipte belirli bir süreye yayılmış kişisel bir izleme olgusu bulunmadığını (176), buradaki izlemeye konu olan bireylerin varılmak istenen amaca göre anonimleştirildiğini, New York, Londra 
ve Madrid'te gerçekleştirilen terör eylemlerinin yarattığ 1 korkunun, bireylerde davranış değişikliklerine yol açacağını ve onları ilerde kitle toplantılarına katılmama, toplu yerlerde bulunmama, toplu taşın araçlarına binmekten kaçınma gibi davranışlara iteceğini (177), kişileri özgür kılmak için bunu önlemenin zorunlu olduğunu, yasada yer alan "halihazır tehlike" kavramının, „eleyici takip“ yönteminin uygulanmasında tek başına ve anılan yöntemin özelliğinden kopuk bir anlamda başvurulacak bir ölçüt olamayacağını, çünkü bu durumda eleyici takip yönteminin başarıya ulaşma şansı bulunmadığını, bu yöntemin tamamlanmasının aylar (olayda 20 ay) sürdügünü, oysa Alman Polis hukukuna göre halihazır tehlikenin, mutlağa yakın bir kesinlikte doğrudan zarar doğurmak üzere olan tehlike anlamına geldiğini, bu anlamda bir tehlikenin zaman bakımından somut tehlike kavramından da kısa ve farklı olduğunu, dolayısıyla eleyici takip kararı için bir önkoşul teşkil edemeyeceğini (178), bu nedenle kuralın yorumunda „tersine oransallık“ kavramının gözönünde tutulması ve ortaya çıkacak zararın ağırlığına göre farklı değerlendirme yapılması gerektiğini, korkulan zarar ne kadar büyükse, zararın ortaya çıkışılla ilgili olasılığı değerlendirmedeki katılı̆̆ın o derece de yumuşatılabileceğini (179) uzman mahkemenin yaptığı değerlendirmenin bu açıdan doğru olduğunu ve anayasal bir sorun teşkil etmediğini savunmaktadır.

HAAS'ın özgürlük ve güvenlik arasında sıkı bağlantı bulunduğu yönündeki düşüncelerinin doğruluk payı oldukça yüksekse de, her iki kavrama adeta aynı ağırlığı vermesi, „özgürlüğün asıl sınırlamanın istisna olduğuna ilişkin" ana ilke ile onun bir uzantısı olan "in dubio pro libertate" ilkesinin uygulanması açısından sakıncalı bir yaklaşımdır. Nitekim yukarda özetlenen karşı oy yazısında bunun izlerini sezmemek mümkün değildir. Özellikle Hıristiyan çoğunluğun güvenliği için, pratikte bütünüyle Müslüman azınlığa yöneltilmiş bir izleme yöntemini, bunun yalnızca aşırı (fundamentalist) dincileri hedef aldığını söyleyerek masumlaştırmaya çalışmak pek de ikna edici gözükmemektedir. Buna karşılık HAAS'ın halihazır tehlike kavramının katı uygulanış biçimiyle eleyici takip arasındaki çelişkiye dikkati çekerek bu alanda tersine oransallık ilkesini devreye sokması ve bunun yanısıra özgürlüğe müdahalenin boyutu ile korunan kamusal çıkarın önemi arasında tartı ve dengeleme yapılmasını önermesi, bize de sıcak görünen ve üzerinde tartışması gereken düşüncelerdir. Ne var ki çoğunluğun halihazır tehlike kavramını HAAS'ın ileri sürdüğü katılıkta değerlendirdiğini söylemek de güçtür. Çoğunluk görüşünün ağırlık noktası, yasada öngörülen halihazır tehlike koşulunun salt 11 Eylül, Londra ve Madrid saldırılarına dayanarak Almanya'da da gerçekleşmiş olduğu sonucuna varılamıyacağı yönündedir. $\mathrm{Bu}$ açıdan bakıldığında Türkiye'deki terör ortamına biraz yaklaşan bir durumun 
Ankara Üniversitesi SBF Dergisi • 62-3

Almanya'nın gündeminde olması halinde, çoğunluk görüşünün Yasa'da öngörülen koşulun uygulanmasını farklı değerlendireceği düşünülmektedir.

$\mathrm{Bu}$ arada çoğunluk görüşünün, yasadaki somut tehlike koşulunu anayasal bir ilke düzeyine çıkarmak suretiyle yasanın uzman mahkemece yorumlanması ve uygulamasına ilişkin bir sorunu anayasal bir sorun olarak değerlendirmesinin bir başka eleştiri konusu olduğuna da işaret etmek gerekiyor. Daha çok uzman mahkemelerle anayasa mahkemesinin yetki alanını ilgilendiren bu konunun ayrıntılarına girmiyoruz. Ancak bu bağlamda Federal Anayasa Mahkemesi'nin bu ve benzer yaklaşımlarının 50 yılı aşkın bir uygulama dönemi içinde terdicen kabul ettirdiği yetki genişlemesinin bir yansıması olduğunu belirtmekle yetiniyoruz.

\section{Avrupa Tutuklama Emri ile İlgili Federal Mahkeme Kararı}

\section{1) Olay:}

Federal Anayasa Mahkemesi'nin 2005 yılında verdiği bu karar ${ }^{18}$, Suriye as1llı bir

Alman vatandaşı ile ilgilidir. Bu kişi hakkında 16.09.2004 tarihinde Madrid 5. Asliye Ceza Mahkemesi'nce bir "Avrupa tutuklama emri" (Europaeischer Haftbefehl) çıkarılmıştır. Kendisine isnat edilen suç, terör örgütü El Kaide'nin Avrupa Şubesi'nde örgütün mali işlerini yürütecek ve üyeleri arasındaki bağlantıyı sağlayacak ş̧ekilde anahtar rolü oynamasıdır. $\mathrm{Bu}$ suçlamalar Avrupa tutuklama emrinde, ilgilinin İspanya ziyaretlerine, olası suç failleri ile buluşma ve telefonlaşmasına dayanılarak ayrıntılı biçimde açılanmaktadır. İspanya soruşturma makamlarına göre, İspanya Ceza Kanunu'nun 515.2 ve 516.2 maddeleri, bu fiillerin yaptırımı olarak 20 yıla kadar hürriyeti bağlayıcı ceza öngörmektedir (1 ve 2).

Bunun üzerine Hamburg Eyalet Yüksek Mahkemesi, 05.11.2004 tarihinde ilgilinin İspanya'ya iade edilmek üzere kesin olarak tutuklanmasına karar vermiştir. Tutuklama kararında Avrupa Tutuklama Emri'ndeki fiillere ek olarak Usame Bin Ladin için bir gemi alınmasına katıldığı, geminin yönetimi ve özellikle belgelerin temini ve hesapların ödenmesi işleriyle görevli olduğu ve Bin Ladin'in Almanya'daki sürekli muhatabı ve asistanı olarak çalıştığı, 2000 yılı sonunda örgütün görevlendirmesiyle Kosova'ya gittiği ve diğer

18 BVerfG, 2 BvR 2236/04 vom 18.7.2005, Absatz-Nr. (1 - 201), http://www. bverfg.de/entscheidungen/rs20050718_2bvr223604.html 
amaçları kamufle etmek üzere oraya bir hasta arabası götürdüğü belirtilmektedir (6 ve 7).

Aynı Mahkeme 23.11. 2004 kararıla da ilgilinin iadesinin caiz olduğuna karar vermiştir (14). Kararda suçun işlendiği tarihte fiilin Almanya'da suç sayılmamasının ilgili açısından ceza kovuşturmasına karşı bir güvence sağlamadığ hukukuna göre suçlu sayılması halinde, Alman vatandaşı da olsa $\mathrm{AB}$ ülkesi bir ülkeye iade edilebileceği belirtilmektedir (15). Hamburg Eyaleti Adalet Bakanlığı da 24.11.2004 tarihinde ilgili kişinin iadesiyle ilgili muvafakat kararı vermiştir. (16).

Federal Anayasa Mahkemesi aynı gün ilgilinin başvurusu üzerine anılan kararın yürütülmesinin durdurulmasına karar vermiş ve bu kararını anayasa şikayetini sonuçlandırıncaya kadar da uzatmıştır (17 ve 18).

İlgili, yaptığı anayasa şikayeti başvurusunda kendisinin iadesinin caiz olduğuna ilişkin Hamburg Eyalet Yüksek Mahkemesi kararı ile Hamburg Eyaleti Adalet Bakanlığı'nın mavafakat kararını hedef almakta ve bu kararların çeşitli anayasal haklarını ihlal ettiğini ileri sürmektedir. İlgilinin başvuru gerekçeleri Federal Anayasa Mahkemesi kararında ele alındığı için burada tekrar edilmeyecektir.

\section{2) Federal Anayasa Mahkemesi Kararı}

Federal Anayasa Mahkemesi'nin bu kararı, iki ana konuda toplanmıştır. Birincisi, Avrupa Tutuklama Emrine İlişkin Yasa'nın Anayasa'ya aykırılığı (aa), ikincisi muvafakat kararına karşı kanun yolunu engelleyen kuralın anayasaya aykırılığı (bb). Tabii bu kuralların Anayasa'ya aykırı bulunması halinde onlara dayalı idari ve yargısal işlemler de Anayasa'ya aykırı duruma gelecektir.

aa) Avrupa Tutuklama Emrine İlişkin Yasa, Avrupa Birliği’nin aynı konudaki çerçeve kararını iç hukuka dönüştüren bir yasadır. Alman Anayasası'nın 16. maddesinin 2. fikrasının ilk cümlesi, "Hiçbir Alman yabancı bir ülkeye iade edilemez." kuralını içermektedir. Bu kural, 29.11.2000 tarihli Anayasa değişikliğine kadar herhangi bir yasa kaydına sahip değildi. Almanya'da bulunan bir Alman vatandaşı, bu tarihe kadar başka ülkelerden gelecek iade taleplerine karşı mutlak bir korumadan yararlanıyordu. Tabii bu mutlak korumanın amacı, yurttaşların yurt dışında işledikleri suçların sorumluluğunu kaldırmak değil, onları, kendi iradeleri olmaksızın, bildikleri, alıştıkları ve güven duydukları hukuk düzeninden uzaklaştırmamaktı (65). Bu kuraldaki mutlak nitelik, aynı zamanda NAZİ Almanyası'ndaki uygulamalara karşı da bir tepkinin ifadesidir (66). Mahkeme bu bağlamda Arupa Birliği 
üyesi olarak Almanya'nın taşıdığı yükümlülüklerin iade konusunu da kapsadığını belirtmekte ve bu konuda Amsterdam ve Nizza andlaşmalarına gönderme yapmaktadır. Bunlara göre, Almanya, "Özgürlük, güvenlik ve hukuk mekanı"nın kuruluşuna ve genişlemesine katkıda bulunmayı taahhüt etmektedir. Bu açıdan üye ülkelerle yapılacak işbirliği, Avrupa Hukuku'nun "hükümetlerarası üçüncü sütunu" alanında gerçekleştirilecektir. Avrupa Birliği Andlaşması'nın 31 maddesinin $1 \mathrm{~b}$ fikrası bu bağlamda üye devletler arasındaki iade konusunun kolaylaştırılmasını öngörmektedir (73).

Buna uygun olarak 2000 y1lında Anayasa'nın 16/2. maddesine nitelikli bir yasa kaydı eklenerek kuralın koruduğu özgürlüğün dokunulmaz niteliği yumuşatılmıştır. Artık Alman vatandaşlarının iadesi, "ancak hukuk devleti ilkeleri korunduğu ölçüde" mümkün olabilecektir. Federal Anayasa Mahkemesi, bu yasa kaydını hukuk devleti ilkesinin bir tekrarı niteliğinde görmemekte, anılan kurala bunu ötesinde bir anlam vermektedir. Mahkeme'ye göre, hukuk devleti ilkelerine, özellikle ölçülülük ilkesine uymak zaten her sınırlamanın bir ön koşuludur. Burada iade talebinde bulunan üye devlet ya da uluslararası mahkeme ile ilgili "yapısal karşıllklılık" anlamında bir ön koşul söz konusudur. Aynı önkoşul Anayasa'nın 23 maddesinin 1. fikrasında ${ }^{19}$ da formüle edilmiştir. Bu nedenle bir Alman vatandaşının iadesine cevaz verecek olan bir yasa, hukuk devletinin bu koşullarının iadeyi talep eden ülke tarafından aynı ölçüde yerine getirilip getirilmediğini de gözönünde tutmakla yükümlüdür ${ }^{20}$ (77). Öte yandan Mahkeme, çerçeve kararın üye devletlere bıraktığı takdir alanını, yasa koyucunun, ilgili temel hak ve özgürlüğü koruyacak biçimde doldurmakla yükümlü olduğunu vurgulamaktadır. $\mathrm{Bu}$ anlamda Avrupa Tutuklama Emrine İlişkin Çerçeve Kararı, AB Andlaşması'ndaki amaçları hukuksal düzeyde yerine getiren bir Birlik işlemi olup, AB Andlaşması'nın 34. maddesinin 2 b fikrasına göre ancak erişilecek amaç açısından bağlayıcıdır. Buna göre Çerçeve Kararı kendiliğinden

19 Alman Anayasası'nın 23. maddesi AB ile ilgili anayasal ilke ve kuralları içermektedir. $\mathrm{Bu}$ maddenin gönderme yapılan 1. fikrasının ilk cümlesi şöyledir: "Federal Almanya Cumhuriyeti, birleşik bir Avrupa'yı gerçekleştirmek üzere, demokratik devlet, hukuk devleti, sosyal devlet, federatif devlet ve ikincillik (Subsidiaritaet) ilkelerine bağlı ve özünde temel hak ve özgürlüklere bu Anayasa ile karşılaştırılabilir nitelikte koruma sağlayan bir Avrupa Birliği'nin gelişimine katkıda bulunur." Görülüyor ki burada öngörülen katkı belli nitelikleri taşıyan bir Avrupa Birliğine yönelik bir katkıdır. Metinde geçen "yapısal karşılıklılık” ile kastedilen de budur.

20 Federal Anayasa Mahkemesi bu açıklamayı yaparken, İspanya ile ilgili herhangi bir değerlendirme yapmaktan kaçınmıştır. 
uygulanmaz, ulusal hukuka dönüştürülmesi gerekir (80). Ayrıca bu dönüştürme yargisal yoldan da sağlanamaz (81).

Federal Anayasa Mahkemesi, Çerçeve Karar'da yer alan bu ve benzer kuralların iç hukukta iadenin sınırlı tutulabilmesini sağladığını belirtmektedir. Mahkemeye göre, bu alanda düzenleme yapacak olan yasa koyucunun müdahale kapsamını belirlerken, hakkın özünü koruma yükümlülüğünün ötesinde yurttaşın iadesini ilke olarak yasaklayan kuralın koruma alanını gözeten bir yaklaşım içinde olması gerekir (83). Buna göre, suç, iade talep eden ülke ile bağlantılı olmakla birlikte esas ağırlığ bakımından Almanya'da işlenmişse, suçlunun iadesi mümkün değildir (85). Buna karşılık suç, esas ağırlığ 1 bakımından iade talep eden ülkede işlenmişse, suçun Almanya ile de bağlantılı olması, iadenin reddi için yeterli bir gerekçe olamaz. Başka bir ülkede suç işleyen bir Alman vatandaşı, bu fiilinden sorumlu tutulacağını hesaba katmak zorundadır. (86).

Mahkeme, Avrupa Tutuklama Emrine İlişkin Yasa'nın yukarda özetlenen anayasal gerekleri karşılamaktan uzak kaldığını belirterek bu konuda aşağıdaki sonuçlara ulaşmaktadır.

aaa) Yasa koyucu, Çerçeve Karar'1 iç hukuka dönüştürürken Alman vatandaşının temel hak düzeyinde özel olarak korunmuş çıkarlarını yeterli ölçüde gözetmemiştir (90). Mahkeme burada "Uluslararası Hukuk Yardımı Yasası"nın çeşitli hükümlerine gönderme yaparak bu yasanın sağladığı olanaklara göre Avrupa Tutuklama Emrine İlişkin Yasa'da boşluklar bulunduğuna işaret etmektedir (92).

bbb) Yasada vatandaşın yabancı bir ülkeye iade edilmeme hakkına yapılacak müdahalenin etkisini özel olarak artıran koşullar gözönünde tutulmamıştır. Bu etki özellikle iadeyi talep eden ülkenin Alman vatandaşı sanığa yönelttiği suçlamanın Alman Hukuku'na göre suç sayılmaması durumunda daha da artmaktadır (93). Oysa Çerçeve Karar bu gibi konularda temel hakları gözetecek bir düzenlemeye açıktır. Örneğin Avrupa Tutuklama Emrine İlişkin Çerçeve Kararı'nın 4. maddesinin 7 a ve b fikraları, suçun, kısmen ya da tamamen iade istenen ülkenin egemenlik alanında işlenmesi, veya iadeyi isteyen ülkenin egemenlik alanı dışında işlenmiş olup da iade talep edilen ülkenin kendi ülkesi dışında işlenmiş bulunan benzer suçların takibine izin vermemesi gibi durumlarda tutuklama emrinin yerine getirilmeyebileceğini öngörmektedir ( 82 ve 99). Buna göre yasa koyucunun her halükarda suçun ağırlıklı olarak ülkede işlenmiş olması halinde bir Alman vatandaşının iadesini reddetme yükümlülüğünü öngörmesi gerekirdi (94). Öte yandan Çerçeve Karar, Avrupa tutuklama emrinin düzenlenmesine dayanak olan fiilin, iade talebine muhatap olan ülkede ceza hukuku yönünden kovuşturulmuş olması veya 
soruşturma makamlarınca takipsizlik kararı verilmesi ya da soruşturmanın kaldırılması gibi durumlarda reddedilebileceğini belirtmektedir ( m. 4/2 ve 3). Böyle durumlarda savcılıkça yapılacak soruşturmalar bireysel hakları koruyucu bir işlev kazanmakta olup, Çerçeve Karar'ın iç hukuka dönüştürülmesinde buna riayet edilmesi gerekir. $\mathrm{Bu}$ bağlamda yasa koyucunun, Ceza Usul Yasası'nı da gözden geçirilerek savcılığın takipsizlik kararlarının olası bir iade talebi açısından denetlenebilir olup olmadığını ya da ne ölçüde denetlenir olması gerektiğini belirlemesi gerekir. Böylece Almanya'yı terketmemiş ve Alman Hukuku'na göre suç işlememiş olan bir vatandaşın iade kararından önceki alanda iadesi engellenmiş olur (95).

ccc) Çerçeve kararın sağladığ 1 takdir alanının tüketici bir biçimde kullanılması ilgili temel hakkın bir gereğidir. Yasa koyucu bundan vazgeçme yetkisine sahip değildir. Yasa koyucu Anayasa'nın yurttaşın iadesini ilke olarak yasaklayan 16/2. maddesinin kendisine yüklediği tartı görevini ihmal etmiş, Avrupa ceza takibatının sınırları aşan gerekleri ile Alman vatandaşı olmanın sağladığ 1 koruma talepleri arasındaki tartıda hataya düşmüştür (96). Yasa koyucu, iade yasağının sağladığı korumayı Anayasa'ya uygun bir biçimde sınırlamak istiyorsa, en azından iade talebini yerine getirecek makamları, hukuk devletinin gerektirdiği belirli olgularla, vatandaşın kendi hukuk düzenine olan güvenini bireysel olayda da dengeleyebileceği bir konuma getirmelidir (97).

ddd) Anayasa'nın 103. maddesinde öngörülen suçta geri yürüme yasağ 1 , maddi ceza hukukunda yapılacak değişikliklerde geçerli olup, suçluların iadesinin de dahil olduğu usul hukukuna ilişkin değişikliklerde geçerli değildir. Ancak 2000 yılına kadar iade karşısında mutlak olarak korunmuş bulunan vatandaşın, Avrupa Birliği üyesi bir ülkede işlenmiş olup, belirleyici nitelikte bir yabancı ülke bağlantısı olmayan ve o tarihte Almanya'da suç sayılmayan fiiller için sorumlu tutulması, maddi ceza hukukunda geriye yürütülen bir değişikliğe eş değerde sayılabilir (98)

eee) Avrupa Tutuklama Emrine İlişkin Yasa'daki eksiklikler, Uluslararası Hukuk Yardımı Yasası'nın 80. maddesinde öngörülen cezanın kendi ülkesinde çekilmesi koşulu ile de dengelenmiş olamaz. Çünkü bu kural yalnızca infazla ilgili olup ceza kovusturması ile ilgili değildir (99). Ayrıca fiilin Almanya'da suç sayılmaması halinde bu koşulun yerine getirilmesi de olanaksizdır (100).

bb) Kararda ayrıca iadeye muvafakat kararının yargısal denetim dışı olması da Anayasa'nın 19/4. maddesinde öngörülen "kamu gücüne karş1 etkili hukuk koruması hakkı"na aykırı bulunmuştur. Bu gerekçenin ayrıntılarına girmiyoruz. 


\section{3) Kararın Değerlendirilmesi}

a) Karşı oy yazılarıyla birlikte 62 sayfayı bulan bu kararda ilk dikkati çeken özellik, somut olayın ikinci planda bırakılmış olmasıdır. Karardaki tüm açıklamalar yasaya yöneltilmiş ve yurttaşın iadesine ilişkin yargısal ya da idari işlemler, yasanın iptalinin sonucu olarak değerlendirilmiştir. Kararın anayasa şikayeti üzerine alınmış olması bu özelliği daha da ilginç bir duruma getirmektedir. Üstelik yasaya yönelik incelemeler somut olayın boyutlarını aşmakta ve adeta bir soyut norm denetimine dönüşmektedir ${ }^{21}$. Yasaya yönelik denetim ise vatandaşlık ve vatandaşın yurt dışına iade edilemiyeceği kuralına odaklanmış olup, suçun uluslararası boyutu, uluslararası terör olgusu ile belirlenmiş niteliği ve buna ilişkin özellikler karar gerekçesinde kendini belli edecek bir ağırlık göstermemektedir.

b) İade talep eden ülke İspanya'dır. İspanya'nın çok ağır bir terör saldırısına uğraması ve iadesi istenen Suriye asıllı Alman vatandaşının bu saldırıda önemli bir rolü üstlenmesi gibi somut bilgi ve veriler, ilgili yasanın kararda büyük bir titizlikle işlenen eksiklikleri yanında adeta değerlendirme dış1 bırakılmıştır. Öyle ki iadenin "ancak hukuk devleti ilkeleri korunduğu ölçüde" yapılabileceğine ilişkin yasa kaydı yorumlanırken, burada öngörülen koşulun iade talebinde bulunan üye devlette de "yapısal karşılıklılık" anlamında aranması gerektiği belirtilmiş ve bu yaklaşım Anayasa'nın 23 maddesinin 1. fikrasına dayandırılmıştır. Alman Anayasası'nın 23. maddesi, AB ile ilgili anayasal ilke ve kuralları içermektedir. $\mathrm{Bu}$ maddenin gönderme yapılan 1 . fikrasının ilk cümlesi şöyledir: "Federal Almanya Cumhuriyeti, birleşik bir Avrupayl gerçekleştirmek üzere, demokratik devlet, hukuk devleti, sosyal devlet, federatif devlet ve ikincillik (Subsidiaritaet) ilkelerine bağll ve özünde temel hak ve özgürlüklere bu Anayasa ile karşılaştırllabilir nitelikte koruma sağlayan bir Avrupa Birliği’nin gelişimine katkıda bulunur." Görülüyor ki burada öngörülen katkı belli nitelikleri taşıyan bir Avrupa Birliği'ne yönelik bir katkıdır. Başka bir deyişle Almanya, bu nitelikleri taşımayan bir AB ülkesine karşı kendisini Birlik amaçlarıyla yükümlü saymamaktadır. Kararda geçen "yapısal karşl1ıklılık" ile kastedilen de budur. Buna göre bir Alman vatandaşının iadesine cevaz verecek olan bir yasa, hukuk devletinin bu koşullarının iadeyi talep eden ülke tarafından aynı ölçüde yerine getirilip getirilmediğini de gözönünde tutmakla yükümlüdür. Mahkeme'nin gerekçesinde İspanya'nın Alman Anayasası'nın yapısal karşılıklııık olarak aradığı nitelikleri taşıyıp taşımadığı konusunda tek bir sözcük kullanılmamıştır. $\mathrm{Bu}$ tutum İspanya'nın bu nitelikte olmadığının iması olarak da değerlendirilebilir.

21 Gerhardt'ın karşı oy yazısında da benzer bir görüş yer alıyor (200). 
Bu doğru ise Avrupa Birliği’nin eşit haklara sahip üyeleri arasında teröre karşı bir zorunluluk olarak ortaya çıkan dayanışma düşüncesi hiç de şık olmayan bir biçimde zedelenmiş demektir. Yok eğer kararı böyle okumak yanlışsa, somut olayla bağı koparıp, yasadaki eksiklik ya da aykırılıkları soyut gerekçelerle açılamak, anayasa şikayetinin somut olaya dönük niteliği ile bağdaşmamaktadir.

Hemen belirtelim ki bu değerlendirmemiz, kararın, Suriye asıllı da olsa bir Alman vatandaşının haklarını korumada gösterdiği duyarlılık ve titizliği görmezlikten gelme anlamına gelmemektedir. Ama bu duyarlılık ve titizlik, somut olayın özellikleri tartışılmadan, bunun norma yansıyıp yansımadığ 1 üzerinde herhangi bir görüş beyan edilmeden salt yasa düzeyinde gösterilmiştir.

b) Kararda göze çarpan bir başka özellik ulusal hukukun önceliğinin vurgulanması ve Avrupa Hukuku ile olan ilişkilerde ikincillik (Subsidiaritaet) ilkesinin ön plana çıkarılmasıdır. Bu konuda GG m. 23/1'de yer alan kuralların, "yapısal karşılıklılık" kavramı ile iade yasağına getirilecek istisnai düzenlemede bir yorum ilkesi olarak yansıtılması, koruma standardının yükseltilmesi bakımından olumlu bir yaklaşımdır. Ancak aynı kuralların (GG m. 23/1) AB içindeki ikili ilişkilere yayılması, birlik ve dayanışma açısından düşündürücüdür. Bu arada Alman kimliğine -biraz da arogant bir biçimde- yapılan vurgu, Türkiye'de ulusallığ 1 Türkiye gündeminden silmeyi ilericilik sayan, ikincillik ilkesini terse çevirip Türk Hukuku'nun Batılıların yüzeysel tepkilerine göre yaz boz tahtasına çevrilmesine teşne olan safdil aydınların dikkatle üzerinde durmaları gereken bir konudur. Türkiye üzerindeki belli hesaplara bilinçli ya da bilinçsiz bir biçimde aracı olanlar, Birlik içinde egemen konumdaki ülkelerin ulusal kimliklerinden vazgeçmeye hiç de eğilimli olmadıklarını bu örnekte açıkça görebilirler. Bundan öğreneceğimiz çok şey olduğuna inanıyorum.

c) Kararın içeriğinde yer alan düşüncelere gelince, çoğunluk kararında Yasa'daki eksikliklerin Çerçeve Karar'da ulusal hukuka bırakılan takdir alanı ile sinırlı tutulması, Avrupada beliren ortak gereksinimlere karşı yine de duyarlı kalındığının bir işaretidir. $\mathrm{Bu}$ açıdan karşı oy yazılarından ikisinin (ya da en azından birinin) daha katı bir yaklaşım içinde olduğu da söylenebilir. Bunlar Yasa'nın Anayasa'ya aykırılığı konusunda aynı görüşte olmakla birlikte gerekçede farklılık göstermektedir. Örneğin Bross'a göre Avrupa Tutuklama Emrine İlişkin Yasa, Çerçeve Karar'ın iç hukuka dönüştürülmesinde yasa koyucunun hatalı davranması nedeniyle değil, Anayasa'nın 23. maddesinin birinci fikrasının ilk cümlesinde yer alan ilkeleri ihlal etmesi nedeniyle Anayasa'ya aykırıdır (133). Bu açıdan Bross, adı geçen kuralın yalnızca bir olanak sağlamadığını, aynı zamanda anayasal bir yükümlülük getirdiğini (136) belirtecek kadar katı bir yaklaşım içindedir. Ona göre bir Alman vatandaşının 
iadesi, ancak tanık ve diğer kanıtların başka bir ülkede bulunması nedeniyle onun Almanya'da yargılanmasının fiilen imkansız olduğu durumlarda söz konusudur $(139,141)$. Buna karşıllı Lübbe-Wolff, Yasa'daki eksiklikleri Anayasa'ya aykırı bulmakla birlikte, bu eksikliklerin yasanın bütününün iptalini haklı kılmadığı görüşündedir (154). Alman Hukuku'nda iptal kararı ilke olarak yasanın yürürlüğe girişinden itibaren hüküm doğurması bakımından Türk Hukuku'ndan farklıdır. Lübbe-Wolff, Yasa'nın bu anlamda iptaline karşı çıkmaktadır. Ona göre, Yasa, yalnızca iadenin ölçülülügünü mümkün kılacak ve bunun için yeterli hukuki korumayı sağlayacak kuralları getirmemiş olması nedeniyle Anayasa'ya aykırıdır. Bu anlamda bir Anayasa ihlalinin önlenmesi için, Anayasa'ya uygun yeni bir yasa yürürlüğe girinceye kadar, Çerçeve Karar'da iade isteminin reddine olanak taniyan 4. maddenin 7 a ya da 7 b fikraları kapsamındaki vatandaşların iadesinin mümkün olamayacağının tespiti yeterlidir. Bunun gibi fiilin suç sayılmaması nedeniyle infazın ülkede gerçekleşemeyeceği durumlarda da aynı tespit yeterli olacaktır (181). Bu açıdan Lübbe-Wolff'un görüşü bizce de, anayasa şikayetine konu olan olayın somut niteliğine daha uygun düşmektedir.

Ancak Yasa'daki eksikliklerin Çerçeve Karar'da ulusal hukuka bırakılan takdir alanı ile sınırlı tutulması konusunda Lübbe-Wolff farklı düşünmektedir. Ona göre, Yasa'nın ilgili temel hak ve özgürlükler açısından iade konusunu düzenlemedeki yetersizliği, yakarıda da belirtildiği gibi, iadenin ölçülülüğünü sağlayacak kural ve kurumların eksikliği ile ilgili bir sorundur ve bunun değerlendirmesi Çerçeve Karar'ın ulusal hukuk için sağladığı takdir alanının kapsamına göre değil, anayasal kural ve ilkelere göre yapılmalıdır (163).

d) Bu kararda Alman Anayasası'nın öngördüğü demokratik devlet, sosyal devlet ve hukuk devleti ilkeleriyle temel hak ve özgürlüklere getirdiği yoğun koruma düzeninin $\mathrm{AB}$ hukukuna ve diğer $\mathrm{AB}$ ülkelerine karşı da vurgulanmas1, başka bir soruyu gündeme getiriyor. Son bir nokta olarak buna değinmeden geçemiyeceğiz: Acaba Madrid olay1, Berlin'de gerçekleşmiş olsaydı, gerek bu eylemle olan bağlantı ve gerekse Ben Ladin'le olan ilişki yönünden mevcut bilgi ve belgeler bir İspanyol vatandaşını suçun faillerinden biri olarak gösterseydi, bu kişinin iadesinin İspanyol Anayasa Mahkemesi'nce önlenmesi Almanya'da nasıl bir tepki doğururdu? Tabii bu sorunun doğru bir soru olmadığının farkındayım. Çünkü Alman makamları iadeye zaten karar vermiş. Soruyu Alman Anayasa Mahkemesi'ne yöneltmek de yanlış, çünkü bu Mahkeme, İspanya Anayasa Mahkemesi'nin vereceği kararı üzerine bir düşünce belirtemez. O halde bu soru neyi ifade ediyor ? Soru, öncelikle Alman Anayasa Mahkemesi kararında böyle bir empatinin izini göremeyişimizden kaynaklanıyor. İkinci neden, birkaç ay önceki bir olay: Yaşı küçük bir Alman'ın Türkiye'de yine yaşı küçük bir İngiliz kızına cinsel tacizde bulunması 
nedeniyle Türk Mahkemesi'nce tutuklanması karşısında Almanya'da koparılan firtına, ister istemez bir çifte standardı akla getiriyor. Türkiye'deki olay incelediğimiz kararların önemine göre oldukça basit bir konu. Ama çifte standardın sorgulanmasında basit konular bazen daha çok işe yarayabiliyor.

\section{Genel Değerlendirme}

\section{1) Çıkarılabilecek Sonuçlar}

Terör çağında özgürlükler konusunu Almanya perspektifi ile inceleyen Ibler, terörle mücadelede yasa koyucunun düzenlemeleri ile Anayasa Mahkemesi kararları arasındaki "deneme - yanılma - öğrenme" sürecinin önemi üzerinde durmakta ve bunun zamanla anılan mücadeleye hukuk devletine ve anayasaya uygun bir nitelik kazandırdığını belirtmektedir ${ }^{22}$. Bu süreçte Ibler'in belirlediği dört ilkeyi ${ }^{23}$ yukarda incelenen kararlardan çıkan sonuç olarak buraya aktarmak yerinde olur:

a) Temel hak ve özgürlüğe müdahale alanı genişledikçe, yasanın dayandı $\breve{g} 1$ nedenlerin haklılığı daha yoğun bir denetime tabi olmaktadır.

b) Müdahalenin biçim ve derecesi, yasanın haklılı̆̆ının belirlenmesinde önem taşımakta, örneğin müdahalenin "eleyici takipte" olduğu gibi gizli tutulması, yasanın haklılığına yönelik denetimi daha da yoğunlaştırmaktadır.

c) Güvenlik öngören yasalarda müdahalenin yoğunluğunu azaltacak denge mekanizmalarının varlığı gerekir. (Yargıç kararı, ilgilinin bilgilendirilmesi ve ceza yargılamasında delil olarak kullanılamama gibi.)

d) Gerek birel işlem düzeyinde ve gerekse yasal yetkilendirme temelinde etkili bir hukuki koruma sağlanmalıdır.

Ibler, bu dört ilkeye ek olarak terörle mücadelede özgürlüğün korunması bakımından elverişli olabilecek başka ilkelere de işaret etmektedir ${ }^{24}$ :

-- Temel hak ve özgürlüklere ilişkin müdahalelerde (koruma alanı, müdahale ve müdahalenin gerekçelendirilmesi) olarak üç aşamada yapılandırılmış bir denetim, kuşku halinde özgürlük lehine sonuç alınmasını özendirmektedir.

-- Bunu tamamlayan bir başka ilke, kuşku halinde ilgili temel hak ve özgürlüğün koruma alanının geniş yorumlanmasıdır. Bunun paraleli kuşku halinde müdahale kavramının geniş yorumlanmasıdır.

22 Ibler, agm, s. 22 vd

23 Ibler, s. 23

24 Ibler, s. 24 vd. 
-- Ibler'in Alman Anayasa Mahkemesi'nin gücüne ve ağırlığına bağladığı ölçülülük ilkesi’nin temel hak ve özgürlüklerin korunmasındaki rolü, Türkiye'de 2001 Anayasa Değişikliğinden sonra tartışmasız bir anayasal ilke niteliği kazanmıştır. Ancak Türkiye'de anayasa şikayeti olmadığı için bu ilkenin soyut ya da somut norm denetiminde etkili olabilmesi, yasalarda ölçülülük denetimini kolaylaştırıcı somut düzenlemelerin varlığına bağlıdır. Bunun ne kadar önemli olduğu Avrupa Tutuklama Emrine İlişkin Yasa'nın denetiminde de görülmüştür.

\section{2) Son Değerlendirme}

$\mathrm{Bu}$ çalışmada hukuk devleti ilkelerini zedelemeden terörle başetmenin yolları üzerinde düşündürücü örnekler sunmaya çalıştık. Bu örnekler gösterdi ki bu konu ülkemizde genellikle algılandığı biçimde basit ve yüzeysel yaklaşımlarla, sınırlayıcı normların -yerine ciddi bir alternatif getirmeksizinkaldırılması yönündeki saf ya da sinsi taleplerle çözülecek bir konu değildir. $\mathrm{Bu}$ anlamda terörün özgürlüğü genişleterek önleneceği görüşü de ciddi bir dayanaktan yoksundur. Terörün hukuk yoluyla önlenmesi, son derece karmaş1k ve uzmanlık gerektiren bir süreçtir. Bu süreç, iyi yetişmiş hukukçuların diğer sosyal bilim dallarının nesnel verilerini hukuk çatısı içinde içselleştirmesiyle başarıya ulaşabilir. Bunun için de siyasal ve ideolojik baskı ve oyunlara karşı gerçekten bağımsız ve güvenceli bir yargı organının varlığı zorunludur. Siyasal ideoloji, kendisine kestirme yollar bulmak için hukuku geriye iterse, bir süre sonra kendi ideolojisini uygulayacağ 1 güvenilir bir hukuk ortamı da bulamaz. Her özgürlük, güvence altına alınan nesnel içeriğine uygun olarak kullanılmasını sağlayacak sınırlamaları göze almak durumundadır. Ancak böyle bir anlayış, o özgürlüğün anayasal ölçütler ve hukuk devleti ilkeleri içinde sınırlanması, uluslararası bir nitelik kazanan terörle de aynı çerçevede mücadele edilmesi yönündeki talebi inandırıcı kılabilir. Ve ancak böyle bir ortamda bu sorunların önyargısız ve objektif bir tartışması mümkün olabilir. 